\title{
Peri-implant bone mechanobiology. Review of the literature
}

\author{
Vanesa Badillo-Perona ${ }^{1}$, Jorge Cano-Sánchez ${ }^{2}$, Julián Campo-Trapero ${ }^{3}$, Antonio Bascones-Martinez ${ }^{4}$ \\ ${ }^{1}$ Graduate in Dentistry, Master of Dentistry Science, Madrid Complutense University \\ ${ }^{2}$ Assistant Professor. Department of Medicine and Buccofacial Surgery, School of Dentistry. Madrid Complutense University \\ ${ }^{3}$ Contracted Professor, Department of Medicine and Buccofacial Surgery, School of Dentistry, Madrid Complutense University \\ ${ }^{4}$ Professor. Head of Medicine and Buccofacial Surgery, Department of Stomatology III, School of Dentistry, Madrid Com- \\ plutense University
}

Correspondence:

Department of Medicine and Buccofacial Surgery

Faculty of Dentistry. Universidad Complutense

28040 Madrid

vanesabadilloperona@,hotmail.com

Badillo-Perona V, Cano-Sánchez J, Campo-Trapero J, Bascones-Martinez
A. Peri-implant bone mechanobiology. Review of the literature. Med Oral
Patol Oral Cir Bucal. 2011 Aug 1;16 (5):e677-81.
http://www.medicinaoral.com/medoralfree01/v16i5/medoralv16i5p677.pdf

Received: $12 / 04 / 2010$

Accepted: 27/05/2010

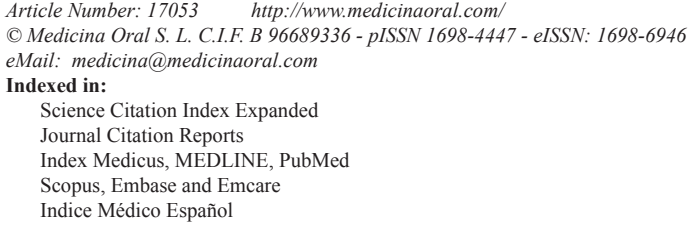

\begin{abstract}
The mechanical load applied during bone regeneration in implant treatments influences the early formation of peri-implant bone tissue through the activation of different pathways. The aim of this review was to determine the currently available scientific evidence in this field.

Material and Method: Electronic search in medical databases (Medline, Pubmed and Cochrane Library) of experimental studies in animal models published from 2003 to 2009.

Results: There is scientific evidence that the immediate application of an axial load in implantology stimulates bone formation, as measured by various histomorphometric parameters. Different physiological mechanisms (e.g., production of nitric oxide, prostaglandin E2) participate in this effect, although their action has not been fully elucidated.

Conclusion: The precise role of mechanical loading in the osseointegration process remains unknown. Further studies are required to demonstrate the biological mechanisms involved and the load range producing the most effective response and to develop devices for obtaining predictable clinical outcomes.
\end{abstract}

Key words: Bone chamber, implant, mechanobiology, tissue differentiation.

\section{Introduction}

The study of bone response to mechanical stimuli has become especially relevant over the past few years because of the development of immediate and early load protocols in implantology. Until recently, it was considered that immediate loading per se was considered responsible for the fibrous encapsulation of the implant. However, it is now known that mechanical stimuli have a marked influence on cells involved in osteogenesis, such as osteocytes $(1,2)$, osteoblasts (3-5), and undifferentiated mesenchymal cells $(6,7)$. In vivo studies have shown that the immediate application of a mechanical load during the bone regeneration phase has a beneficial effect on osseointegration (8-15).

Nevertheless, there are few data on devices that take advantage of this osteogenic capacity of mechanical 
stimuli in implant treatments or on the most effective application mode.

The objective of this paper was to review the available scientific evidence on the response of peri-implant bone to controlled mechanical loading during bone regeneration in animal biomodels, measured by different histomorphometric parameters, on the physiological mechanisms involved, and on the most effective loading ranges.

\section{Material and Methods}

Medical databases Medline, Pubmed and Cochrane Library were searched for reports published between 2003 and 2009 on animal models in which the immediate application ( $<48 \mathrm{~h}$ after implant placement) of a controlled axial load on dental implants is studied. An inclusion criterion was that the study employed a device to permit control and quantification of the forces applied. All journals were found in the Index-Medicus and library of the School of Dentistry of the Madrid Cumplutense University. The loading protocols collected were compared by analyzing the different peri-implant responses recorded by histological and/or histomorphometric studies.

\section{Results and Discussion}

1. Response of peri-implant bone in implants with controlled axial load versus no load.

The selected studies (Table 1) were in vivo experimental studies on animal models, conducted with titanium implants located in the tibia and adapted to a device for controlling the force applied. The use of such a device permits investigation of bone formation around the implant in: a) a stable implant environment with no movement; and b) in a mechanically altered environment associated with a controlled axial force, isolating the implant from external influences.

Duyck et al. designed a bone growth chamber that permits observation of peri-implant bone regeneration and allows the implant to be subjected to a specific type of loading (11). This bone chamber has been used in various studies (8-10, 13-15), yielding the following results: - Bone Area Fraction (BAF), five studies (8-10, 12,13). Vandamme et al. found that the BFA was larger in loaded versus unloaded implants and found a higher value in those subjected to an axial displacement of $90 \mu \mathrm{m}(9,12)$. A significant difference in application time between loaded and non-loaded implants was reported by these authors but was not observed by Duyck et al. (13).

- Osteoid-to-implant contact (OIC): three studies $(9,10,12)$. Vandamme et al. reported a greater OIC in loaded versus non-loaded implants, finding a higher value in those subjected to an axial displacement of $90 \mu \mathrm{m}$ (9) and in implants loaded at 12 versus 6 weeks (10).

-Bone-to-implant contact(BIC): five studies $(9,10,12,13,15)$. Vandamme et al. $(9,10,12)$ found a higher BIC value in loaded versus non-loaded implants. In contrast, Duyck et al. reported a lower BIC value in loaded implants, using a similar study design and duplicating the load cycles, suggesting that a loading of less than 800 cycles produces an increase in the BIC, although the exact limit was not defined (15). This difference may also be due to a different localization of the histological section, since Geris et al. found that the site of this section has a significant effect on histomorphometric measurements of BIC and BAF variables (8).

- Bone-and-osteoid-to-implant contact (BOIC): one study (12). The BOIC was found to be higher in loaded versus non-loaded implants.

- Tissue Area Fraction (TAF): two studies $(9,10)$. Vandamme et al. reported a similar TAF between implants subjected to a displacement of 30 and $90 \mu \mathrm{m}$ (9) and a higher TAF in loaded implants at 12 weeks (10).

- Non-mineralized and Mineralized Bone Fraction (nMB and MB fractions): two studies $(9,10,12)$ The $\mathrm{Mb}$ fraction was higher in loaded implants, whereas the nMB was not affected by implant loading $(10,12)$, although another study by the same authors (9) reported a higher $\mathrm{nMB}$ fraction in implants loaded to displacements of 30 and $90 \mu \mathrm{m}$.

- Bone Fraction (BF): one study (13). The BF was found to be higher in loaded versus non-loaded implants.

- Total Tissue Volume (TTV): one study (15) A higher TTV was found in implants loaded to a displacement of 60 versus $30 \mu \mathrm{m}$.

- Bone Volume Fraction (BVF): one study (15). The BVF was found to be similar between control implants and those subjected to a displacement of $90 \mu \mathrm{m}$ and was higher in both than in implants with a displacement of $30 \mu \mathrm{m}$.

- Bone Density (BD): one study (15). BD was reported to be higher in loaded versus non-loaded implants.

In the selected studies, all implants were loaded immediately after their placement except in the investigation by Leuch et al. (14), which did not report the timing of loading. Studies considerably differed in load protocol, geometry, implant surface, and load duration (between 3 days and 12 weeks). The articles describe a cyclic loading of 400-800 cycles, in which, according to Kaspar et al., an appropriate cell response is expected (16). This number is defined as a function of the daily contact between teeth during mastication and deglutition.

It should be borne in mind that the implants in the selected studies were extracted for histological study, and this extraction may itself cause cell damage. There have been recent reports on the use of non-invasive methods to avoid this possible alteration, including "virtual biopsies" using high-resolution 3-D imaging systems, (17). Other authors have used Resonance Frequency Analysis (RFA) values to determine the effects of immediateearly loading (18). 
Table 1. Studies included in the review.

\begin{tabular}{|c|c|c|c|c|c|c|}
\hline Authors & $\begin{array}{c}\text { Implant } \\
\text { type }\end{array}$ & $\mathbf{R a}$ * & Sample & $\begin{array}{c}\text { Load protocol } \\
\#\end{array}$ & Time & Results $\dagger$ \\
\hline $\begin{array}{c}\text { Geris } \\
2008 \\
(8)\end{array}$ & $\begin{array}{l}\text { Cylindrical } \\
V s . \text { screw }\end{array}$ & 0.70 & $\begin{array}{l}10 \text { mice } \\
\text { Female }\end{array}$ & $\begin{array}{l}\text { I: immediate } \\
\text { CC: } 400 \\
\text { D: } 30 \mu \mathrm{m} \\
\text { F: } 1 \mathrm{~Hz} \\
\text { T: } 3 \mathrm{t} / \text { week }\end{array}$ & 9 weeks & $\begin{array}{l}\text { BAF: no significant differences between the } \\
\text { implant types. } \\
\text { BIC: superior in screw implants }(\mathrm{P}=0.01)\end{array}$ \\
\hline $\begin{array}{l}\text { Vandamme } \\
2007 \\
(12)\end{array}$ & $\begin{array}{l}\text { Cylindrical } \\
\text { Vs. screw }\end{array}$ & 0.70 & $\begin{array}{l}10 \text { mice } \\
\text { Female }\end{array}$ & $\begin{array}{l}\text { I: immediate } \\
\text { LC: } 400 \\
\text { D: } 30 \mu \mathrm{m} \\
\text { F: } 1 \mathrm{~Hz} \\
\text { T: } 3 \mathrm{t} / \text { week }\end{array}$ & 9 weeks & $\begin{array}{l}\text { BAF: inferior in non-loaded vs. loaded screw } \\
\text { implants }(\mathrm{P}<0.0001) \text {; similar in both types } \\
\text { subjected to load. } \\
\text { nMB: not affected by load or by geometry. } \\
\text { MB: superior in loaded implants. } \\
\text { OIC, BIC and BOIC: superior in loaded implants } \\
(\mathrm{P}<0.0001)\end{array}$ \\
\hline $\begin{array}{l}\text { Leucht } \\
2007 \\
(14)\end{array}$ & Cylindrical & NR & $\begin{array}{l}45 \text { mice } \\
\text { Male }\end{array}$ & $\begin{array}{c}\text { I: NR } \\
\text { RC: } 0-2.27 \mathrm{Kg} \\
\text { D: } 150 \mu \mathrm{m} ; \\
\text { F: } 1 \mathrm{~Hz} \\
\text { LD: } 60 \mathrm{~s} \\
\text { T: daily }\end{array}$ & $\begin{array}{l}3,7,14,21 \\
\text { and } 28 \\
\text { days }\end{array}$ & $\begin{array}{l}\text { Formation of new bone similar between day } 7 \\
\text { with load and day } 14 \text { without load. }\end{array}$ \\
\hline $\begin{array}{c}\text { Vandamme } \\
2007 \\
(9)\end{array}$ & Screw & 2.75 & $\begin{array}{l}10 \text { mice } \\
\text { Female }\end{array}$ & $\begin{array}{c}\text { I: immediate } \\
\text { LC: } 400 \\
\text { D: } 0,30,60 \mathrm{y} \\
90 \mu \mathrm{m} \\
\text { F: } 1 \mathrm{~Hz} \\
\text { T: } 3 \mathrm{t} / \text { week }\end{array}$ & 9 weeks & $\begin{array}{l}\text { TAF: no significant differences among the three } \\
\text { load conditions. } \\
\text { BAF: superior in implants loaded to } 90 \mu \mathrm{m} \\
\text { displacement } v \text { s. no load }(\mathrm{P}=0.0031) \\
\text { nMB: superior in implants loaded to } 30 \text { and } 90 \\
\mu \mathrm{m} \text { displacement } v s \text {. non-loaded ( } \mathrm{P}=0.00217 \\
\text { and } \mathrm{P}<0.0001) \\
\text { MB: superior in implants loaded to } 30 \text { and } 90 \\
\mu \mathrm{m} \text { displacement } v \text { s. no load }(\mathrm{P}<0.0001) \\
\text { OIC: increases with load }(0 v s \text {. } 30 \mu \mathrm{m}: \mathrm{P}= \\
0.0184 \text {; } 0 \text { vs. } 90 \mu \mathrm{m}: \mathrm{P}=0.0017) \text { superior in } \\
\text { implants loaded to } 90 \mu \mathrm{m} v s \text {. } 30 \mu \mathrm{mt}(\mathrm{P}= \\
0.0042) \text {. } \\
\text { BIC: superior in implants loaded to } \mathrm{s} 90 \mu \mathrm{m} v s \text {. } \\
30 \mu \mathrm{m}(\mathrm{P}=0.0097) \text { and without load }(\mathrm{P}=0.0004)\end{array}$ \\
\hline $\begin{array}{l}\text { Vandamme } \\
2007 \\
(10)\end{array}$ & Cylindrical & 0.45 & $\begin{array}{l}14 \text { mice } \\
\text { Female }\end{array}$ & $\begin{array}{c}\text { I: immediate } \\
\text { LC: } 400 \text { y } 800 \\
\text { D: } 30,50 \mu \mathrm{m} \\
\text { F: } 1 \mathrm{~Hz} \\
\text { T: } 2 \mathrm{t} / \text { week }\end{array}$ & $\begin{array}{l}6 \text { and } 12 \\
\text { weeks }\end{array}$ & $\begin{array}{l}\text { TAF: significantly higher in implants loaded } 12 \\
\text { weeks vs. } 6 \text { weeks }(\mathrm{P}<0.0001) \text { and } 12 \text { weeks } \\
\text { without load }(\mathrm{P}<0.0001) \text {. } \\
\text { BAF: significantly different among the three load } \\
\text { conditions }(6 \mathrm{w}-\text { load } v s . \quad 12 \mathrm{w}-\text { load: } \mathrm{P}<0.0001 \text {; } \\
\text { 12w-load } v s .12 \mathrm{w} \text {-without load: } \mathrm{P}=0.0408 ; 6 \mathrm{w}- \\
\text { load } v s .12 \mathrm{w} \text {-without load: } \mathrm{P}=0.0013) \text {. } \\
\text { MB: superior at } 12 \text { weeks with load vs. } 6 \text { weeks } \\
\text { with load ( } \mathrm{P}<0.0001) \text { and non-loaded }(\mathrm{P}< \\
\text { 0.0001). } \\
\text { nMB: no significant differences among the } \\
\text { different load conditions. } \\
\text { OIC and BIC: superior at } 12 \text { weeks with load ( } v s \text {. } \\
6 \mathrm{w}-\text { load: } \quad \mathrm{P}<0.0001 ; \quad 12 \mathrm{w} \text {-without load: } \\
\mathrm{P}=0.0001) \text {. }\end{array}$ \\
\hline $\begin{array}{l}\text { Duyck } \\
2007 \\
(13)\end{array}$ & Screw & $\begin{array}{c}2.75 \text { vs. } \\
0.45\end{array}$ & $\begin{array}{l}5 \text { mice } \\
\text { Female }\end{array}$ & $\begin{array}{l}\text { I: immediate } \\
\text { LC: } 400 \\
\text { D: } 30 \mu \mathrm{m} \\
\text { F: } 1 \mathrm{~Hz} \\
\text { T: } 3 \mathrm{t} / \text { week } \\
\end{array}$ & 6 weeks & $\begin{array}{l}\text { BAF: no significant differences among groups } \\
\text { (rough without load; mechanized without load; } \\
\text { rough with load; mechanized with load) } \\
\text { BF: superior in loaded implants. }\end{array}$ \\
\hline $\begin{array}{l}\text { Duyck } \\
2006 \\
(15)\end{array}$ & Cylindrical & 0.45 & $\begin{array}{l}10 \text { mice } \\
\text { Female }\end{array}$ & $\begin{array}{c}\text { I: immediate } \\
\text { LC: } 800 \\
\text { D: } 0,30,60 \text { and } \\
90 \mu \mathrm{m} \\
\text { F: } 1 \mathrm{~Hz} \\
\text { T: } 2 \mathrm{t} / \text { week }\end{array}$ & 6 weeks & $\begin{array}{l}\text { TTV: inferior in non-loaded implants; in loaded } \\
\text { implants, significantly superior those loaded to } \\
60 \mu \mathrm{m} v s .30 \mu \mathrm{m} \text {. } \\
\text { BVF: similar in non-loaded and loaded to } 90 \mu \mathrm{m} \text {; } \\
\text { significantly superior in both than in loaded } \\
30 \mu \mathrm{m} \text {. } \\
\text { BD: superior in those loaded to } 60 \text { and } 90 \mu \mathrm{m} v s \text {. } \\
\text { non-loaded. } \\
\text { BIC: superior in non-loaded implants. }\end{array}$ \\
\hline
\end{tabular}

NR: non-recorded; * Implant surface roughness $(\mu \mathrm{m}) ; \uparrow$ Moment when measurements are made after applying mechanical load; \# I: time of load initiation after surgery; LC: load cycles; D: axial displacement of implant; F: frequency; T: application time; LD: Load duration; † BAF: Bone Area Fraction; BIC: Bone-to-implant contact; nMB: Non-Mineralized Bone Fraction; MB: Mineralized Bone Fraction; OIC: Osteoidto-implant contact; BOIC: Bone-and-osteoid-to-implant; TAF: Tissue Area Fraction; BF: Bone Fraction; TTV: Total Tissue Volume; BVF: Bone Volume Fraction; BD: Bone Density. 
There is no consensus on the levels of axial displacement that are excessive or on those that yield superior outcomes, because of the difficulty of comparing among studies, since the response is influenced by the implant geometry and microtopography and by the implantation site.

However, despite this lack of uniformity in study design, it is clear that immediate controlled mechanical loading has a beneficial effect on implant osseointegration.

2. Physiological mechanisms triggering mechanical forces in the bone

Bone responds actively to mechanical tension via more complex pathways than previously acknowledged. Various theories have been proposed.

According to the Canalicular Fluid Flow hypothesis presented by Cowin et al. in 1991, interstitial fluid in loaded bone is squeezed through the non-mineralized matrix towards Haversian or Volkman canals or, in trabecular bone, towards the bone marrow. This flow of fluid has two main functions: the transport of nutrients and waste products and mechanotransduction (19). Osteocytes respond to mechanical stimulus by producing signaling molecules that modulate the activity of osteoblasts and osteoclasts, converting the mechanical stimulus into intracellular signals $(2,19)$.

An in vitro study published by Burger et al. in 1999 demonstrated that a pulsatile fluid flow regulates bone production by increasing nitric oxide (NO) (20). NO acts rapidly on intercellular communication, acting as local inhibitor of the osteoclastic attack $(1,19)$ and protecting osteocytes against apoptosis (2).

One of the first events in the cascade of signals that takes place in bone mechanotransduction is the mobilization of intracellular calcium, which can transmit extracellular signals to the interior of the cell and potentially to the genome. In vitro and in vivo studies have shown that the application of an oscillatory fluid flow to bone cells produces a rapid increase in intracellular calcium, and that this calcium mobilization is required for the regulation of osteopontin (OPN) mRNA $(20,21)$. Other signaling molecules are reported to be involved, including prostaglandin-E2 (PGE2) (3) associated with the induction of cyclooxygenase-2 (COX-2) (21).

Bakker et al. demonstrate that introduction of pulsatile fluid flow changes the expression of Bcl-2 apoptosisregulating gene, increasing its expression and increasing the $\mathrm{Bcl}-2 / \mathrm{Bax}$ ratio after one hour in a dose-dependent manner (1).

\section{The most effective loading range}

Although it has been observed that immediate loading does not inhibit osseointegration, loading conditions are decisive for the implant prognosis (15). It appears that if a hitherto poorly defined micromovement threshold is exceeded, damage could be caused to the fibrin network and to new vessels in formation, and the differen- tiation of undifferentiated mesenchymal cells towards osteoblasts may be compromised (22). Hence, two types of micromovement can be differentiated: tolerated and deleterious.

Researchers do not agree on the level of micromotion that can be considered excessive. It is difficult to compare studies, given that results are influenced by numerous variables as well as by the displacement of the implant.

\section{Conclusions}

The precise role of mechanical loading in the osseointegration process remains to be elucidated, due to the difficulty of controlling and isolating ideal loading conditions. Animal studies have been facilitated by the design of devices that permit control over these forces. However, extrapolation to the effect of immediate loading in humans is hampered by the difficulty of isolating and controlling the force exerted on the implant. Therefore, the consequences of immediate loading are not currently predictable, and further research is required to establish the most favorable loading protocol for periimplant bone response.

\section{References}

References with links to Crossref - DOI

1. Bakker A, Klein-Nulend J, Burger E. Shear stress inhibits while disuse promotes osteocyte apoptosis. Biochem Biophys Res Commun. 2004;320:1163-8.

2. Tan SD, de Vries TJ, Kuijpers-Jagtman AM, Semeins CM, Everts V, Klein-Nulend J. Osteocytes subjected to fluid flow inhibit osteoclast formation and bone resorption. Bone. 2007;41:745-51.

3. Batra NN, Li YJ, Yellowley CE, You L, Malone AM, Kim CH, et al. Effects of short-term recovery periods on fluid-induced signaling in osteoblastic cells. J Biomech. 2005;38:1909-17.

4. Myers KA, Rattner JB, Shrive NG, Hart DA. Osteoblast-like cells and fluid flow: cytoskeleton-dependent shear sensitivity. Biochem Biophys Res Commun. 2007;364:214-9.

5. Sato K, Adachi T, Ueda D, Hojo M, Tomita Y. Measurement of local strain on cell membrane at initiation point of calcium signaling response to applied mechanical stimulus in osteoblastic cells. J Biomech. 2007;40:1246-55

6. Haasper C, Jagodzinski M, Drescher M, Meller R, Wehmeier $\mathrm{M}$, Krettek C, et al. Cyclic strain induces FosB and initiates osteogenic differentiation of mesenchymal cells. Exp Toxicol Pathol. 2008;59:355-63.

7. Sumanasinghe RD, Bernacki SH, Loboa EG. Osteogenic differentiation of human mesenchymal stem cells in collagen matrices: effect of uniaxial cyclic tensile strain on bone morphogenetic protein (BMP-2) mRNA expression. Tissue Eng. 2006;12:3459-65.

8. Geris L, Vandamme K, Naert I, Vander Sloten J, Duyck J, Van Oosterwyck H. Application of mechanoregulatory models to simulate peri-implant tissue formation in an in vivo bone chamber. J Biomech. 2008;41:145-54.

9. Vandamme K, Naert I, Geris L, Vander Sloten J, Puers R, Duyck $J$. The effect of micro-motion on the tissue response around immediately loaded roughened titanium implants in the rabbit. Eur J Oral Sci. 2007;115:21-9.

10. Vandamme K, Naert I, Geris L, Sloten JV, Puers R, Duyck J. Histodynamics of bone tissue formation around immediately loaded cylindrical implants in the rabbit. Clin Oral Implants Res. 2007; 18:471-80.

11. Duyck J, Cooman MD, Puers R, Van Oosterwyck H, Sloten JV, 
Naert I. A repeated sampling bone chamber methodology for the evaluation of tissue differentiation and bone adaptation around titanium implants under controlled mechanical conditions. J Biomech. 2004;37:1819-22.

12. Vandamme K, Naert I, Geris L, Vander Sloten J, Puers R, Duyck J. Influence of controlled immediate loading and implant design on peri-implant bone formation. J Clin Periodontol. 2007;34:172-81.

13. Duyck J, Slaets E, Sasaguri K, Vandamme K, Naert I. Effect of intermittent loading and surface roughness on peri-implant bone formation in a bone chamber model. J Clin Periodontol. 2007;34:9981006.

14. Leucht P, Kim JB, Wazen R, Currey JA, Nanci A, Brunski JB, et al. Effect of mechanical stimuli on skeletal regeneration around implants. Bone. 2007;40:919-30.

15. Duyck J, Vandamme K, Geris L, Van Oosterwyck H, De Cooman M, Vandersloten J, et al. The influence of micro-motion on the tissue differentiation around immediately loaded cylindrical turned titanium implants. Arch Oral Biol. 2006;51:1-9.

16. Kaspar D, Seidl W, Neidlinger-Wilke C, Beck A, Claes L, Ignatius A. Proliferation of human-derived osteoblast-like cells depends on the cycle number and frequency of uniaxial strain. J Biomech. 2002;35:873-80.

17. Cano J, Campo J, Vaquero JJ, Martínez González JM, Bascones A. High resolution image in bone biology II. Review of the literature. Med Oral Patol Oral Cir Bucal. 2008;13:E31-5.

18. Quesada-García MP, Prados-Sánchez E, Olmedo-Gaya MV, Muñoz-Soto E, González-Rodríguez MP, Valllecillo-Capilla M. Measurement of dental implant stability by resonance frequency analysis: a review of the literature. Med Oral Patol Oral Cir Bucal. 2009;14:e538-46.

19. Klein-Nulend J, Bacabac RG, Mullender MG. Mechanobiology of bone tissue. Pathol Biol (Paris). 2005;53:576-80.

20. Burger EH, Klein-Nulen J. Responses of bone cells to biomechanical forces in vitro. Adv Dent Res. 1999;13:93-8.

21. Bakker AD, Klein-Nulend J, Burger EH. Mechanotransduction in bone cells proceeds via activation of COX-2, but not COX-1. Biochem Biophys Res Commun. 2003;305:677-83.

22. Brunski JB, Puleo DA, Nanci A. Biomaterials and biomechanics of oral and maxillofacial implants: current status and future developments. Int J Oral Maxillofac Implants. 2000;15:15-46. 